\title{
Emerging Trends in Healthcare-A Path to the Future
}

\author{
Gokul Venkateshwar ${ }^{1 *}$, Ekta Keswani ${ }^{2}$ and Sumeet Shinde ${ }^{3}$ \\ ${ }^{1}$ Professor, Oral and Maxillofacial Surgery, DY Patil School of Dentistry, DY Patil \\ University, Navi Mumbai, India \\ ${ }^{2}$ Associate Professor, Oral and Maxillofacial Surgery, DY Patil University School of \\ Dentistry, Navi Mumbai, India \\ ${ }^{3}$ Post Graduate, Oral Maxillofacial Surgery, DY Patil University School of Dentistry \\ Navi Mumbai, India \\ *Corresponding Author: Gokul Venkateshwar, Professor, Oral and Maxillofacial \\ Surgery, DY Patil School of Dentistry, DY Patil University, Navi Mumbai, India.
}

DOI: $10.31080 /$ ASDS.2020.04.0898

The last few months has compelled us look at healthcare through the prism of the Covid 19 pandemic, the path of trajectory of the contagion points to the surge of the pandemic leading to a huge public health crisis. Despite the lockdowns imposed by several Governments across the world, the pandemic shows no signs of abating, with the daily fluctuating graph being a point of vexatious debate. The adamant virus has managed to leave its footprints everywhere leading to an enormous challenge being thrown on our healthcare system, traditionally entrenched in combating diseases prevalent in our society. Though in recent years in the last decade or so the virus crisis has manifested as SARS, H1N1, Swine flu, the current zenith of Covid 19 has surpassed the viruses prevalence hitherto known to the world in a short span of time. The pandemic has ravaged societies across the countries and created economic and social imbalances affecting all strata of the society in developed and developing nations as well. This pandemic is no longer confined to the boundaries of any nation, its prevalence today is across continents, threatening to upend humanity. Today we stand at the edge of a precipice, staring at a crisis at a time when our civilization is trying to achieve its pinnacle. The impact of health on our socio economic structure, is undeniable and we no longer can push it under a carpet and ignore it anymore.

The pandemic today has put immense strain on the overstretched resources and has thrown up a host of questions, whether we are actually prepared to face this health emergency now and in the future. What would define the future in emerging new healthcare trends?

Four pillars of necessity are the core strategies to prevent this from happening tomorrow.
Received: July 15, 2020

Published: July 28, 2020

(C) All rights are reserved by Gokul

Venkateshwar., et al.
One is a strong Government role in healthcare. Today as we are staring at a crisis, Governments are under tremendous pressure to combat this deadly epidemic which brings us to the question about health care delivery system and budgetary allocations for Health. A robust public health care system is the need of the hour. State Governments along the Central Government should take the lead in streamlining the health care delivery in working in tandem with local authorities. Since in our country private sector has a huge stake in healthcare collaboration with private hospitals is the need of the hour. A public private partnership can lead the efforts which can ensure a just participation of private players with Govt agencies to augment the efforts. Health policy framers, govt agencies involved in health care policies should get a prime position in national strategies and no longer can be ignored. Expert panels involving a wide strata of the society to get feedbacks is the need of the hour. Schemes like Ayushman Bharat should be popularized for the common man, as insurance cover among the general public is very low. Budgetary allocations for health sector should be substantial to enhance the delivery, and necessary safeguards should be in place to ensure that the benefits reaches the poor. Malnutrition is another burning question in impoverished societies, and unfortunately put on the backburner, which needs to be answered as we are seeing that immunity is directly related to the pandemic. An inherent solution to circumvent established epidemics and new contagions is to combat malnutrition aggressively as a nationwide campaign on similar lines as Swaccha Bharat Abhiyan is needed. Preventive and Public medicine again can help in stemming diseases, however we see this aspect completely ignored. Epidemiology must be given its due place in the pantheon of medicine, today this field has emerged as a vital aspect in the vigil and fight against the pandemic. Govt 
agencies must have epidemiologists as key opinion leaders on their panel.

Govt can play a huge role in popularizing preventive healthcare through propaganda through its various channels. Urban Rural imbalances in the health sector should be improvised, or a seamless green channel should be made in case a patient from a rural area desires specialty treatment in an urban centre, a separate facility should be provided to them.

The second pillar is the active role of nodal agencies like World Health Organization (WHO). A health watchdog at the international level actively monitoring outbreaks with early warning systems can prevent epidemics like Covid 19. Unfortunately even now several nations are either ignoring warnings or avoiding steps to be taken in the fight against the pandemic. The WHO has taken the lead for curbing Ebola virus in Africa. It becomes imperative that nodal agencies take a lead and collaborate with governments across the world and have a transparent liasioning with them at all levels. Every alert from nodal agencies with the outlook of possible contagion should be taken seriously in the wake and clampdown and measures initiated without delay. Governments and WHO should establish a network where pandemics can be monitored at a global level. Interlinking and analyzing of data from countries can help recognize emerging threats. Today we are no longer a citizen of our country, with technology outreach, with our realm as globalised citizens, the purview of healthcare now should be seen in a global perspective. International non-governmental organizations like Medicine Sans Frontiers are a beacon of hope in the developing countries where Govt's struggle to offer basic health care. Govt should encourage national non -governmental organizations to strategize and deliver care in an impartial way.

The third pillar is Research. Western nations have taken a lead in research of drugs and vaccines, path breaking inventions in centers of excellence has revolutionized healthcare, benefitting humanity at large. Our country needs to invest in this area, we have a large pool of talented young minds who can lead the revolution in research, many discoveries were made in laboratories accidentally, today we no longer can afford to let our guard down to invisible enemies and behooves us to focus on emerging diseases and combat them with all our might. Covid is having sustained impact on our socio economic scenario, putting us in a quandary situation where no one is safe from the threat of new maladies. Similarly, research in vaccine technology, generic drugs can be brought about by mak- ing research careers more attractive in the coming years where AIIMS like centre's can focus on research.

The fourth pillar is sanitation and hygiene. In our country we are faced lack of sanitation facilities, clean drinking water and proper hygiene measures adopted by the public, thereby making us prone to infection. Migration has created invisible pools of floating population in search of work. Schemes like MREGA should be popularized and funds allocated to give more work in rural areas. Urban areas have dense population with people living in close quarters and amenities are sparse. Spitting in public places in the single biggest problem faced by us, as lot of infectious diseases can be transmitted. Public Hygiene should be prioritized as these measures can help in curbing the rise of diseases. Sustained efforts like campaigns, innovative methods to create awareness in hygiene can go a long way in tackling the menace of pandemics. Ground level health workers in sync with Government machinery can identify health issues in communities prone to infection.

The Epidemic Diseases Act an ancient piece of legislation of 1897 from the British Era needs to be relooked into and provisions for hefty penalties or as a bailable offence which can be introduced by law for spitting, misusing public places for defecating etc. should be enacted in the future session of Parliament after lockdown.

This edition of pandemic is not new, in 1918 the Spanish flu affected millions across the world laying waste across vast swathes of population roughly a fourth of the worlds was affected, we are facing a similar situation today in the new strain of the virus replicated in a different avatar. Today healthcare is facing new challenges to treat patients. As perplexed clinicians are focused on containing the pandemic through permutations and combinations, attention is being shifted away from non covid patients, routine efforts to eradicate infectious diseases are being compromised which cannot be ignored amidst the pandemic. We need to put equal effort in managing these patients by taking appropriate measures. Also in view of the social ostracizing of healthcare workers in covid duties, efforts should be taken to dispel fears in the minds of the general public about the reversibility of the infection and the fact that adequate protective measures permits doctors to work in a covid environment without contacting it. In the face of the new enemy Preventive measures, greater role of nodal agencies and non- governmental organizations, recognizing emerging threats, sustained efforts and intensive campaigning, research in new areas of drugs, universal vaccinations, solving malnutrition, improving 
public hygiene and sanitation measures and adapting newer methods in healthcare are some of the emerging trends though they are already there in the established system impetus is required in a big way. Pandemics will come and go. Covid 19 has developed into a full blown crisis, though we have recognized its threat albeit lately, it appears that we can avert and limit this in a long drawn war. Now a new societal order where health care should take precedence should be the new mantra as our progress is inherently linked to the well being of mankind [1-3].

\section{Bibliography}

1. Gopalan., et al. "Covid -19 pandemic and challenges for socioeconomic issues, healthcare and National Health Programs in India". Diabetology and Metabolic Syndrome 14.5 (2020): 757758.

2. Chakraborty., et al. "Covid 19 Outbreak; Migration, effects on society, global environment and prevention". Science of the Total Environment 728 (2020): 138882.

3. "The Social challenge in times of COVID 19". Economic Commission for Latin America and Caribbean.

\section{Assets from publication with us}

- Prompt Acknowledgement after receiving the article

- Thorough Double blinded peer review

- Rapid Publication

- Issue of Publication Certificate

- High visibility of your Published work

Website: www.actascientific.com/

Submit Article: www.actascientific.com/submission.php

Email us: editor@actascientific.com

Contact us: +919182824667 